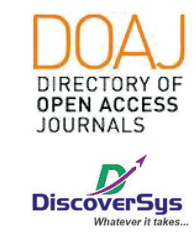

Published by DiscoverSys

\title{
Interval waktu iskemia, derajat iskemia, dan sindrom kompartemen merupakan faktor risiko amputasi pada pasien acute limb ischemia yang dilakukan tindakan trombektomi terbuka di RSUP Sanglah Denpasar
}

\author{
Dea Emmanuel, ${ }^{1 *}$ Ketut Putu Yasa, ${ }^{2}$ Ida Bagus Putra Manuaba, ${ }^{3}$ I Nyoman Semadi, ${ }^{2}$ \\ Ketut Widiana, ${ }^{4}$ Gede Wirya Kusuma Duarsa ${ }^{5}$
}

\section{ABSTRACT}

Introduction: Acute Limb Ischemia (ALI) is a sudden decrease in perfusion in the extremities that causes the threat of tissue viability and is still one of the causes of disability. The purpose of this study was to determine the factors that influence amputation in patients with acute limb ischemia who undergo thrombectomy.

Methods: This was a retrospective observational study with casecontrol studies. As many as 40 patients with acute limb ischemia who underwent thrombectomy were seen as an outcome of amputation. Matching was done based on age and sex in the case (amputation) and control (without amputation) groups. Data collection is based on medical records from 2014 to 2019. Bivariate analysis uses Chi-Square or Fisher's Test while multivariate analysis uses logistic regression.
Results: In this study we found that the time interval of ischemia and the degree of ischemia is a risk factor of amputation in person with ALI $(p<0.05)$ but compartment syndrome was not significantly related to amputation in ALI. Multivariate analysis shows degree of Rutherford IIB/III ischemia to be a the most dominant factor for amputation $(0 \mathrm{R}=6.84 ; 95 \% \mathrm{Cl}=1.19-39.35$; $p=0.03)$.

Conclusion: The time interval of ischemia and the degree of ischemia are factors that influence amputation in patients with acute limb ischemia who undergo thrombectomy. The degree of ischemia is the most dominant risk factor affecting amputation.
1Program Pendidikan Dokter Spesialis Bedah, Fakultas Kedokteran Universitas UdayanaRSUP Sanglah Denpasar, BaliIndonesia

${ }^{2}$ Sub Bagian Bedah Thoraks dan Kardiovaskular, Departemen/KSM IImu Bedah, Fakultas Kedokteran Universitas Udayana-RSUP Sanglah Denpasar, Bali-Indonesia ${ }^{3}$ Program Pasca Sarjana Biomedik, Fakultas Kedoktera Universitas Udayana, Bali-Indonesia

${ }^{4}$ Sub Bagian Bedah Onkologi, Departemen/KSM IImu Bedah, Fakultas Kedokteran Universitas Udayana-RSUP Sanglah Denpasar, Bali-Indonesia

${ }^{5}$ Sub Bagian Bedah Urologi, Departemen/KSM IImu Bedah, Fakultas Kedokteran Universitas Udayana-RSUP Sanglah Denpasar, Bali-Indonesia

*Correspondence to: Dea Emmanuel, Program Pendidikan Dokter Spesialis Bedah, Fakultas Kedokteran Universitas Udayana-RSUP Sanglah Denpasar, Bali-Indonesia dea.emmanuel07@gmail.com

Diterima: 07-05-2020 Disetujui: 10-07-2020 Diterbitkan: 01-08-2020
Keywords: Ischemic Time Interval, Ischemia Degrees, Compartment Syndrome, Acute Limb Ischemia, Thrombectomy Cite This Article: Emmanuel, D., Yasa, K.P., Manuaba, I.B.P., Semadi, I.N., Widiana, K., Duarsa, G.W.K. 2020. Interval waktu iskemia, derajat iskemia, dan sindrom kompartemen merupakan faktor risiko amputasi pada pasien acute limb ischemia yang dilakukan tindakan trombektomi terbuka di RSUP Sanglah Denpasar. Intisari Sains Medis 11(2): 808-813. D0I: 10.15562/ism.v11i2.753

\section{ABSTRAK}

Latar Belakang: Acute Limb Ischemia (ALI) adalah penurunan secara tiba-tiba perfusi di ekstremitas sehingga menyebabkan ancaman viabilitas jaringan dan masih menjadi salah satu penyebab disabilitas Tujuan dari penelitian ini adalah untuk mengetahui faktor faktor yang mempengaruhi amputasi pada pasien acute limb ischemia yang dilakukan trombektomi.

Metode: Penelitian ini merupakan penelitian observasional retrospektif dengan studi kasus kontrol. Sebanyak 40 pasien acute limb ischemia yang dilakukan trombektomi dilihat outcomenya dari amputasi. Dilakukan matching berdasarkan usia dan jenis kelamin pada kelompok kasus (amputasi) dan kontrol (tanpa amputasi). Pengambilan data berdasarkan catatan medis dari tahun 2014 hingga
2019. Analisa bivariat menggunakan Chi-Square atau Uji Fisher sedangkan analisa multivariat menggunakan regresi logistik.

Hasil: Berdasarkan analisa statistik didapatkan didapatkan interval waktu iskemia dan derajat iskemia mempengaruhi amputasi $(p<0,05)$ namun sindrom kompartemen tidak berhubungan secara signifikan. Hasil multivariat dengan regresi logistik ditemukan derajat iskemia Rutherford IIB/III menjadi faktor dominan terjadinya amputasi (OR = 6.84 ; IK $95 \%=1,19-39,35 ; p=0,03)$.

Simpulan: Interval waktu iskemia dan derajat iskemia merupakan faktor yang mempengaruhi amputasi pada pasien acute limb ischemia yang dilakukan trombektomi. Derajat iskemia merupakan faktor risiko yang paling dominan mempengaruhi amputasi.
Kata kunci: Interval Waktu Iskemia, Derajat Iskemia, Sindrom Kompartemen, Acute Limb Ischemia, Trombektomi Cite Pasal Ini: Emmanuel, D., Yasa, K.P., Manuaba, I.B.P., Semadi, I.N., Widiana, K., Duarsa, G.W.K. 2020. Interval waktu iskemia, derajat iskemia, dan sindrom kompartemen merupakan faktor risiko amputasi pada pasien acute limb ischemia yang dilakukan tindakan trombektomi terbuka di RSUP Sanglah Denpasar. Intisari Sains Medis 11(2): 808-813. D0I: 10.15562/ism.v11i2.753 


\section{PENDAHULUAN}

Acute Limb Ischemia (ALI) adalah penurunan secara tiba-tiba perfusi di ekstremitas sehingga menyebabkan ancaman viabilitas jaringan. Secara klinis disebut $A L I$ apabila menimbulkan gejala kurang dari 2 minggu. Sampai saat ini ALI masih merupakan masalah kesehatan, hal ini karena insiden, keterlambatan penanganan, amputasi dan mortalitas masih tetap tinggi. Di Amerika Serikat didapatkan insiden ALI sebesar 26 per 100.000 penduduk. Tingkat amputasi berkisar $25 \%$ dan in hospital mortality berkisar antara 9-15\%. Keterlambatan penanganan pasien $A L I$ akan meningkatkan risiko amputasi. $^{1}$

Faktor yang sangat menentukan adalah lamanya iskemia dan derajat iskemia, semakin lama iskemia terjadi akan semakin meningkatkan derajat iskemia. ${ }^{2,3}$ Derajat dari $A L I$ sendiri sebenarnya menggambarkan kerusakan sel dan jaringan, baik itu endotel, otot maupun saraf dengan gejala klinis berupa 6 P, yaitu: pain, pallor, poikilothermia, paresthesia, dan paralysis. Komponen dari $6 \mathrm{P}$ tersebut yang menjadi dasar pembagian kriteria dari Rutherford ditambah dengan konfirmasi pulsasi dari arteri dan vena berdasarkan ultrasonografi. Rutherford menbagi derajat ALI menjadi I, IIA, IIB dan III. ${ }^{3,4}$ Keadaan emboli yang lama $>6$ jam akan mempunyai prognosis yang buruk. Tindakan revaskularisasi segera yaitu trombektomi harus segera dilakukan.

Tindakan trombektomi yang dilakukan pada iskemia yang lama dapat menyebabkan terjadinya peningkatan tekanan intra kompartemen yang disebut sindrom kompartemen. Terjadi ekstravasasi cairan dan respon inflamasi setelah keadaan iskemia-reperfusi. ${ }^{4,5}$ Sindrom kompartemen harus dikenali dengan cepat karena akan menyebabkan kerusakan pada ekstremitas.

Berdasarkan permasalahan tersebut, penelitian ini bertujuan untuk mengetahui pengaruh faktor-faktor yang berperan terhadap keberhasilan tindakan revaskularisasi dengan trombektomi pada pasien ALI.

\section{METODE}

Penelitian ini merupakan penelitian observasional retrospektif dengan studi kasus kontrol. Kelompok kasus adalah pasien ALI yang mengalami amputasi setelah trombektomi, kelompok kontrol dipilih sesuai dengan jumlah kasus. Kelompok kontrol adalah pasien ALI yang tidak mengalami amputasi setelah trombektomi. Kemudian dilakukan matching berdasarkan usia dan jenis kelamin. Penelitian ini menggunakan data dari catatan rekam medis pasien dari tahun 2014 sampai 2019. Variabel bebas yang dinilai adalah interval waktu iskemia, derajat iskemia dan sindrom kompartemen. Sementara variabel terikat adalah amputasi setelah trombektomi. Variabel kendali yaitu: umur, jenis kelamin, atrial fibrilasi, rhematic heart disease, diabetes mellitus, hipertensi dan pemberian heparin. Analisis data dalam penelitian ini menggunakan bantuan SPSS versi 25.0 untuk Windows. Analisis bivariat menggunakan Chi square atau Uji Fisher serta permodelan risiko menggunakan rasio odds (OR), kemudian analisis multivariat menggunakan regresi logistik untuk mengetahui faktor risiko yang paling dominan. Seluruh nilai dianggap bermakna apabila $\mathrm{p}<0,05$.

\section{HASIL PENELITIAN}

Dari data yang diperoleh selama tahun 2014 sampai 2019 terdapat 40 pasien ALI yang dilakukan tindakan trombektomi, dimana 20 pasien dengan amputasi dan 20 pasien tanpa amputasi. Karakteristik sampel penelitian dapat dilihat pada tabel 1, tidak ditemukan adanya perbedaan karakteristik berdasarkan usia, jenis kelamin, kondisi diabetes dan hipertensi, atrial fibrilasi, penyakit jantung reumatik, penggunaan heparin sebelum dan pasca tindakan, dan fasiotomi antara kelompok kasus (amputasi) dan kontrol (tidak amputasi) $(p>0,05)$. Sedangkan interval waktu iskemia yang lebih dari 6 jam, derajat iskemia IIB/III lebih banyak ditemukan pada kelompok yang mengalami amputasi $(\mathrm{p}<0,05)$.

Interval waktu iskemia pada kelompok kasus (amputasi) > 6 jam sebanyak 17 responden (68\%) dan pada kelompok kontrol (tanpa amputasi) sebanyak 8 responden (32\%). Interval waktu <6 jam pada kelompok amputasi 3 responden $(20 \%)$ dan pada kelompok tanpa amputasi 12 responden (80\%). Nilai Odds Ratio (OR) 8,5 (95\% IK: 1,18-38,31) berarti interval waktu iskemia $>6$ jam menyebabkan amputasi sebanyak 8.5 kali dengan nilai $\mathrm{p}=0.003$, ada hubungan antara interval waktu iskemia dengan amputasi pasca trombektomi (Tabel 2).

Derajat iskemia IIB/III pada kelompok kasus (amputasi) sebanyak 15 responden (78,9\%) dan pada kelompok kontrol (tanpa amputasi) sebanyak 4 responden $(21,1 \%)$. Derajat iskemia IIA pada kelompok amputasi sebanyak 5 responden $(23,8 \%)$ dan pada kelompok tanpa amputasi 16 responden (76,2\%). Nilai Odds Ratio (OR) 12,0 (95\% IK: 2,7-53,33), berarti interval waktu iskemia IIB/ III menyebabkan amputasi sebanyak 12 kali dan nilai $\mathrm{p}<0,001$ menunjukkan ada hubungan yang signifikan antara derajat iskemia dengan amputasi pasca trombektomi (Tabel 2). 
Sindrom kompartemen pada kelompok amputasi sebanyak 1 responden (14\%) dan kelompok tanpa amputasi 19 responden (85,7\%) sementara pada yang tidak sindrom kompartemen pada kelompok amputasi sebanyak 19 responden $(57,6 \%)$ dan kelompok tanpa amputasi sebanyak 14 responden (42,6\%). Nilai Odds Ratio 0.12 (95\% IK: 0,013-1,13) dan nilai $p=0,091$. Hal ini berarti sindrom kompartemen tidak berhubungan secara signifikan dengan amputasi pasca trombektomi (Tabel 2).

Analisis multivariat menunjukkan derajat Iskemia dengan nilai OR 6.84 berarti interval waktu iskemia memberikan peluang terjadinya amputasi sebanyak 6.84 kali. Hal ini dapat disimpulkan faktor risiko yang paling dominan menyebabkan amputasi pasca trombektomi adalah derajat iskemia (Tabel 3).

\section{Tabel 1 Karakteristik subjek penelitian}

\begin{tabular}{|c|c|c|c|}
\hline \multirow[b]{2}{*}{ Variabel } & \multicolumn{2}{|c|}{ Amputasi } & \multirow[b]{2}{*}{ Nilai $p$} \\
\hline & $\mathrm{Ya}(\mathrm{n}=\mathbf{2 0})$ & Tidak $(n=20)$ & \\
\hline Usia (tahun (rerata + SD) & $60,00+13,42$ & $61,15+18,02$ & 0.82 \\
\hline \multicolumn{4}{|l|}{ Jenis Kelamin (n,\%) } \\
\hline Laki-laki & $9(50 \%)$ & $9(50 \%)$ & 1,00 \\
\hline Perempuan & $11(50 \%)$ & $11(50 \%)$ & \\
\hline \multicolumn{4}{|l|}{ Interval waktu iskemia (n,\%) } \\
\hline$>6$ jam & $17(68 \%)$ & $8(32 \%)$ & 0,003 \\
\hline$<6$ jam & $3(20 \%)$ & $12(80 \%)$ & \\
\hline \multicolumn{4}{|l|}{ Derajat iskemia $(\mathbf{n}, \%)$} \\
\hline IIB/III & $15(78,9 \%)$ & $4(21,1 \%)$ & $<0,001$ \\
\hline IIA & $5(23,8 \%)$ & $16(76,2 \%)$ & \\
\hline \multicolumn{4}{|c|}{ Kompartemen sindrom (n,\%) } \\
\hline Ya & $1(14,3 \%)$ & $6(85,7 \%)$ & 0,091 \\
\hline Tidak & $19(57,6 \%)$ & $14(42,4 \%)$ & \\
\hline \multicolumn{4}{|l|}{ Diabetes melitus (n,\%) } \\
\hline Ya & $6(66,7 \%)$ & $3(33,3 \%)$ & 0,45 \\
\hline Tidak & $14(45,2 \%)$ & $17(54,8 \%)$ & \\
\hline \multicolumn{4}{|l|}{ Hipertensi (n,\%) } \\
\hline Ya & $14(48,3 \%)$ & $15(51,7 \%)$ & 0,72 \\
\hline Tidak & $6(54,5 \%)$ & $5(45,5 \%)$ & \\
\hline \multicolumn{4}{|l|}{ Atrial fibrilasi (n,\%) } \\
\hline Ya & $10(41,7 \%)$ & $14(58,3 \%)$ & 0,19 \\
\hline Tidak & $10(62,5 \%)$ & $6(37,5 \%)$ & \\
\hline \multicolumn{4}{|c|}{ Rheumatic heart disease (n,\%) } \\
\hline Ya & $2(33,3 \%)$ & $4(66,7 \%)$ & 0,66 \\
\hline Tidak & $18(52,9 \%)$ & $16(47,1 \%)$ & \\
\hline \multicolumn{4}{|l|}{ Heparin pre tindakan $(n, \%)$} \\
\hline Ya & $17(45,9 \%)$ & $20(54,1 \%)$ & 0,23 \\
\hline Tidak & $3(100 \%)$ & $0(0 \%)$ & \\
\hline \multicolumn{4}{|l|}{ Heparin post tindakan $(n, \%)$} \\
\hline Ya & $18(47,4 \%)$ & $20(52,6 \%)$ & 0,48 \\
\hline Tidak & $2(100 \%)$ & $0(0 \%)$ & \\
\hline \multicolumn{4}{|l|}{ Fasciotomi (n,\%) } \\
\hline Ya & $1(14,3 \%)$ & $6(85,7 \%)$ & 0,091 \\
\hline Tidak & $19(57,6 \%)$ & $14(42,4 \%)$ & \\
\hline
\end{tabular}


Tabel 2 Analisa bivariat hubungan antara interval waktu iskemia, derajat iskemia dan kompartemen sindrom dengan amputasi

\begin{tabular}{|c|c|c|c|c|c|}
\hline \multirow[b]{2}{*}{ Variabel } & \multicolumn{2}{|c|}{ Amputasi } & \multirow[b]{2}{*}{ OR } & \multirow[b]{2}{*}{ IK 95\% } & \multirow[b]{2}{*}{ Nilai $p$} \\
\hline & $Y a(n=20)$ & Tidak $(n=20)$ & & & \\
\hline \multicolumn{6}{|c|}{ Interval waktu iskemia } \\
\hline$>6$ jam & $17(68 \%)$ & $8(32 \%)$ & 8,5 & $1,18-38,31$ & 0,003 \\
\hline$<6$ jam & $3(20 \%)$ & $12(80 \%)$ & & & \\
\hline \multicolumn{6}{|c|}{ Derajat iskemia } \\
\hline IIB/III & $15(78,9 \%)$ & $4(21,1 \%)$ & 12,0 & $2,70-53,33$ & $<0,001$ \\
\hline IIA & $5(23,8 \%)$ & $16(76,2 \%)$ & & & \\
\hline \multicolumn{6}{|c|}{ Kompartemen sindrom } \\
\hline $\mathrm{Ya}$ & $1(14,3 \%)$ & $6(85,7 \%)$ & 0,12 & $0,013-1,13$ & 0,091 \\
\hline Tidak & $19(57,6 \%)$ & $14(42,4 \%)$ & & & \\
\hline
\end{tabular}

Tabel 3 Analisa multivariat pengaruh interval waktu dan derajat iskemia terhadap amputasi

\begin{tabular}{lccc}
\hline Variabel & OR & IK 95\% & Nilai p \\
\hline Interval waktu iskemia & 2,81 & $0,44-17,73$ & 0,27 \\
Derajat iskemia & 6,84 & $1,19-39,35$ & 0,03 \\
\hline
\end{tabular}

\section{PEMBAHASAN}

\section{Hubungan antara interval waktu iskemia dengan amputasi}

Emboli arteri merupakan suatu keadaan kegawatdaruratan pada penyakit arteri perifer dimana akan terjadi keadaan iskemia pada jaringan yang disebabkan oleh karena oklusi pada arteri. Acute limb ischemia (ALI) merupakan manifestasi klinis dari keadaan ini dimana keadaan iskemia yang lama akan menyebabkan gangguan pada status hemodinamik dan menyebabkan gagal organ sistemik karena pelepasan dari metabolit anaerobik kedalam sirkulasi sistemik selama proses iskemia berlangsung (Mutirangura, 2009). Durasi iskemia akan berkorelasi dengan derajat iskemia merupakan faktor risiko yang akan mempengaruhi luaran dari terapi. Penelitian yang dilakukan oleh Mutirangura et al. ${ }^{6}$ terhadap 91 pasien dengan emboli arterial akut pada ekstremitas bawah didapatkan hasil 31 pasien $(34,1 \%)$ dengan early acute embolism $(<24$ jam) dan 60 pasien $(65,9 \%)$ dengan late acute embolism (>24 jam). Gangren yang luas didapatkan pada pasien dengan late acute embolism $(26,7 \%$ vs $3,2 \%$, p $=$ $0,009)$ dan angka amputasi lebih tinggi $(20 \%$ vs $3,2 \%, \mathrm{p}=0,05)$.

Menentukan kapan tindakan trombektomi pada keadaan ALI masih merupakan perdebatan sampai saat ini. Dari penelitian lain yang dilakukan oleh Ljungman et al. ${ }^{7}$ didapatkan hasil bahwa waktu iskemia yang lama akan meningkatkan risiko amputasi (OR 4,3; IK 95\%: 1,9-9,6) pada iskemia $>25$ jam dibandingkan dengan iskemia $<6$ jam. $^{7}$

\section{Hubungan antara derajat iskemia dengan amputasi}

Berdasarkan guideline dari American Heart Association, manifestasi klinis dari Penyakit Arteri Perifer dibagi menjadi empat, yaitu: asimptomatik, klaudikasio, critical limb ischemia dan acute limb ischemia. Acute limb ischemia didefinisikan sebagai penurunan seketika perfusi ke tungkai yang menyebabkan ancaman viabilitas jaringan dengan onset kurang dari 2 minggu. ${ }^{8}$

Kriteria ALI berdasarkan Rutherford dibagi menjadi I, IIA, IIB dan III. Hasil penelitian ini dari tabel 2 didapatkan hasil terjadi peningkatan risiko amputasi pada grade IIB/III dibandingkan IIA (OR 12,0; IK 95\%: 2,70-53,33; $p<0,001$ ). Pada tabel 3 dari analisis multivariat didapatkan faktor yang paling dominan mempengaruhi amputasi adalah derajat iskemia (OR 6,84, IK 95\%: 1,19-39,35; p=0,03).

Hasil penelitian ini sejalan dengan penelitian yang dilakukan oleh Genovese et al. ${ }^{9}$ yang menyatakan bahwa risiko amputasi akan meningkat sejalan dengan meningkatnya derajat iskemia (Rutherford IIB dibandingkan dengan IIA; HR: 2,57; $\mathrm{p}<0,001)$.

Derajat dari ALI menurut Rutherford dibagi menjaditiga kategori. Penentuan derajat berdasarkan 
adanya pulsasi arteri dan vena (dengan Doppler ultrasonografi) adanya sensasi dan fungsi motorik. Derajat dari $A L I$ sendiri sebenarnya menggambarkan kerusakan sel dan jaringan, baik itu endotel, otot maupun saraf dengan gejala klinis berupa 6P, yaitu: pain, pallor, poikilothermia, paresthesia, dan paralysis. Komponen dari 6P tersebut yang menjadi dasar pembagian kriteria dari Rutherford ditambah dengan konfirmasi pulsasi dari arteri dan vena berdasarkan ultrasonografi.

\section{Hubungan antara sindrom kompartemen dengan amputasi}

Penelitian yang dilakukan oleh Feliciano et al. di selama pengamatan 9 tahun pada 122 pasien trauma diperoleh hasil bahwa 75\% amputasi pada ekstremitas bawah berhubungan dengan keterlambatan tindakan fasiotomi atau fasiotomi yang tidak sempurna. ${ }^{10}$ Oleh karena itu pasien paska tindakan revaskularisasi yang dicurigai akan mengalami sindrom kompartemen harus dilakukan monitoring yang ketat. Meskipun demikian faktor-faktor yang berhubungan dengan sindrom kompartemen masih belum jelas, sehingga kewaspadaan dan tindakan preventif untuk mencegah sindrom kompartemen sukar untuk dilakukan. Studi oleh Papalambros et al. ${ }^{11}$ yang melaporkan bahwa faktor risiko terjadinya sindrom kompartemen yaitu: waktu iskemia $>6$ jam, usia muda ( $<45$ tahun), riwayat ALI sebelumnya pada ekstremitas inferior, dan inadekuat backflow paska tindakan revaskularisasi.

Pada penelitian ini didapatkan hasil pada pasien yang mengalami sindrom kompartemen semuanya dilakukan fasiotomi. Dari hasil tabel 2 didapatkan tingkat amputasi pada pasien yang dilakukan fasiotomi lebih rendah dibandingkan yang tidak $(14,3 \%$ vs $57,6 \%, p=0,091)$ namun secara statistik tidak bermakna. Pada penelitian ini didapatkan hanya 7 pasien yang mengalami kompartemen sindrom dan semuanya dilakukan fasiotomi sehingga kemungkinan hal tersebut juga menjadi faktor dapat menyebabkan ketidak bermaknaan yang ditemui secara statistik pada penelitian ini.

Pada beberapa penelitian sebelumya meskipun tindakan profilaksis fasiotomi dapat menurunkan insiden amputasi, beberapa penelitian lain menunjukkan bahwa tindakan ini tidak terlalu bermanfaat pada pasien-pasien dengan usia yang lanjut dan dengan indeks masa tubuh yang rendah. ${ }^{12}$ Sementara itu penelitian lainnya oleh Endicott et al. menunjukkan bahwa pada pasien $A L I$ yang dilakukan trombektomi dan profilaksis fasiotomi terjadi peningkatan operasi ulangan atau re-operasi (OR 1,6; IK 95\%: 1,2-2,0; $\mathrm{p}<0,01$ ), sehingga disarankan untuk melakukan tindakan fasiotomi yang selektif pada pasien $A L I .^{13}$

\section{SIMPULAN}

Interval waktu iskemia dan derajat iskemia merupakan faktor yang mempengaruhi amputasi pada ALI pasca trombektomi. Dari penelitian ini derajat iskemia menjai faktor yang paling dominan mempengaruhi amputasi. Oleh karena itu diagnosis ALI harus ditegakkan dalam waktu yang cepat, dan tindakan trombektomi dilakukan dalam waktu $<6$ jam.

\section{ETIKA DALAM PENELITIAN}

Penelitian ini telah mendapatkan persetujuan dari Komite Etik Fakultas Kedokteran Universitas Udayana/RSUP Sanglah Denpasar dengan nomer referensi kelaikan etik 08/UN14.2.2.VII.14/LP/2020.

\section{KONFLIK KEPENTINGAN}

Penulis menyatakan tidak terdapat konflik kepentingan terkait publikasi dari penelitian ini.

\section{PENDANAAN}

Penelitian ini tidak mendapatkan pendanaan dari pemerintah ataupun sektor swasta lainnya.

\section{DAFTAR PUSTAKA}

1. Baril DT, Ghosh Kaushik, Rosen Allison B. Trend in the incidence, treatment, and outcome of acute lower extremity ischemia in the United States Medicare Population. Journal of Vascular Surgery. 2014;60(3):669-677.

2. Mutirangura $P$ et al. Acute Arterial Embolism of the Lower Extremities:Impact of 24 Hour Duration on the Outcome of Management. Journal Med Association Thailand. 2008; 91(9):1360-7.

3. Orrapin S, Orrapin M, Arwon S, Rerkasem K. Predictive Factors for Post Ischemic Compartment Syndrome in Non Traumatic Acute Limb Ischemia in Lower Extremity. Annals of Vascular Disease. 2017;10(4):378-385.

4. Rutherford RB. Clinical Staging of Acute Limb Ischemia as a Basis Choice of Revascularization Method: When and How to Intervene. Seminars in Vascular Surgery 2009;22:5-9.

5. Simon F, et al. Acute Limb Ischemia-Much More Than Just a Lack of Oxygen. International Journal of Molecular Science. 2018;19(2):1-16.

6. Mutirangura $\mathrm{P}$, et al. Clinical differentiation between acute arterial embolism and acute arterial thrombosis of the lower extremities. J Med Assoc Thai. 2009;92(7):891-7.

7. Ljungman C, Holmberg L, Bergqvist D, Bergsrom R, Adami Hans O. Amputation Risk and Survival after Embolectomy for Acute Arterial ischemia. Time Trends in a Defined Swedish Population. European Journal of Vascular and Endovascular Surgery. 1996; 11:176-182.

8. Hardman RL, et al. Overview of Classification System in Peripheral Artery Disease. Semin Intervent Radiologi. 2014;31(4):378-388. 
9. Genovese EA, Chaer RA, Taha AG, Marone LK, Averinos E, Makaroun MS, Baril DT. Risk factors for long term mortality and amputation after open and endovascular treatment of acute limb ischemia. Ann Vasc Surg. 2016;30:82-92.

10. Feliciano DV, Herskowitz K, O'Gorman RB. Management of vascular injuries in the lower extremities. J Trauma. 1988;28:319-328.

11. Papalambros EL, Panayiotopoulos YP, Bastounis E, et al Prophylactic fasciotomy of legs following acute arterial occlusion procedures. Int Angiol. 1989;8:120-4.

12. Alizadegan S. Old Tradition of Prophylactic Fasciotomy Could Be Avoided. Journal of Vascular Surgery. 2018;68(3):1-7.
13. Endicott Kendal M. Selective Use of Fasciotomy with Emergent Lower Extremity Embolectomy Demonstrates Comparable 30-Days Amputation Rates. Journal of Vascular Surgery. Journal of Vascular Surgery. 2018;67(6):139-140.

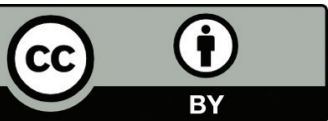

This work is licensed under a Creative Commons Attribution 